\title{
NIEBLA MAL SUMINISTRADA
}

\section{Tomás SÁNCHEZ SANTIAGO}

A José Enrique, que ya atendía por entonces a la poesía

sí llama un viejo amigo mío a la memoria, sobre todo a partir de cierta edad, cuando lo
próximo desaparece entre vedijas opacas (¿qué desayuné hoy? ¿dónde puse las llaves? ¿a
qué vine a la cocina?) y lo remoto se presenta de manera imprevista y con facilidad extraña, como una escena otorgada de golpe por manos de dioses desconocidos. Una niebla mal suministrada. Nunca he encontrado una definición mejor para esa gimnasia improbable de los bandazos del pensamiento cuando reculan sin norma hacia atrás en busca de aquello que les ordenamos y que, según instrucciones desconocidas, viene o no viene. Y todo por su cuenta. Lo digo porque lanzo el boomerang a ver si vuelve y no, no vuelve, no logro distinguir la primera vez que me vi con José Enrique; recuerdo, eso sí, que el año en que llegué a León él impartía un curso sobre poesía contemporánea y tuvo la generosidad —o la osadía — de dar mi nombre a un alumno que deseaba hacer un trabajo de fin de carrera. Fue su primera atención, a la que seguiría una sucesión de gestos hospitalarios que a mí me abrumaban. Enseguida entramos en esa otra fase de cercanía en que el profesor va cediendo paso al amigo. Quedábamos para charlar ante cervezas o cafés; dábamos pequeños paseos por la ciudad, acompañándonos mutuamente... No resultó difícil observar cómo sobre la estatura del conocedor de la poesía estaba la del ser humano, que se impuso enseguida con esa naturalidad con que se muestran quienes no desean exponer en su forma de ser extremos desentendidos. Y ahí ya tuve por seguro que había encontrado un amigo en León. Aún más, un interlocutor poético que - luego lo vi claroatendía con bisturí a menudo piadoso cuanto en la provincia iba apareciendo: libros, colecciones, aventuras poéticas juveniles...; él lo ha atendido todo, hasta hoy, con esa vibración que solo se encuentra en las criaturas que saben aliar rigor y bondad.

La naturaleza de textos como este que escribo suele ser encomiástica, es verdad; lo exige el protocolo. Uno quisiera escapar de esa ortopedia triste de la formalidad con estas palabras, que no responden a la obligación sino a la alegría («donde hay obligación no hay alegría», decía un personaje de Julio Verne), la alegría de haber encontrado a alguien capaz de atender, con justicia y entusiasmo, esa casa del temblor: la poesía 
Pero el recado quedaría incompleto si no le devolviera a él, a José Enrique, la materia encendida con la que ambos traficamos vivamente durante estos años desde que nos encontramos algún día de 1993. Seguimos haciéndolo.

\section{CONFIGURACIÓN DEL VERANO}

I

ahora sí, ahora sí,

dentelladas flamantes...

la de la luz de julio sobre el río,

emplumándolo de agujas y de joyas veloces,

la del sudor y sus ondulaciones

húmedas sobre los cuerpos saqueados

por los pactos del calor,

la de los gritos impuros de los niños

en lo alto de la noche,

vivos y tardíos

entre dos patios aún calientes

entra ahora el verano

con su mugido hermoso

y arden sin sueño los seres

y la nobleza corta de las noches

dame a mí del manto de tus días

una orilla sin ánimo,

un puñado de hilo de asustadas sustancias

cosas de poco amparo

donde nunca habrán de llegar a beber

esos otros animales, los que traen hirviendo

entre los dientes

la lenta gelatina de la desolación 
318 Tropelías. Revista de Teoría de la Literatura y Literatura Comparada, número extraordinario 1 (2017) Tomás Sánchez Santiago

II

por el cielo, qué ruido

de astas sucias

la tormenta...

deja enferma la luz

al final de la tarde

un brillo de limones sumergidos

viene a por ti

el verano

¿y tú? ¿darás la espalda

a su cromo lujoso

de jardines candentes y de abejas bravías?

no, esta vez no

quémate en su aventura

de metales nocturnos y de túnicas

rojas, desabrochadas

a favor de los cuerpos

entra

en la onda dormida de la carne

y abrásate despacio allí,

junto a todos,

junto a todo

en la respiración incandescente

de perros, de frutas y medallas

que abrasan

el pecho de las niñas maldormidas 